\title{
Rhizospheric Fungi to Plant Growth Promotion: A Review
}

\author{
João Manoel da Silva \\ Rede Nordeste de Biotecnologia, Instituto de Química e Biotecnologia, Universidade Federal \\ de Alagoas, Brazil
}

Yamina Coentro Montaldo, Arthur Costa Pereira Santiago de Almeida

Campus de Engenharias e Ciências Agrárias, Universidade Federal de Alagoas, Brazil

\section{Viviane Araújo Dalbon}

Rede Nordeste de Biotecnologia, Instituto de Química e Biotecnologia, Universidade Federal de Alagoas, Brazil

Juan Pablo Molina Acevedo

Colombian Corporation for Agricultural Research Agrosavia, Colombia

Tania Marta Carvalho dos Santos, Gaus Silvestre de Andrade Lima

Campus de Engenharias e Ciências Agrárias, Universidade Federal de Alagoas, Brazil

Received: November 19, 2020 Accepted: December 27, 2020 Published: February 19, 2021 doi:10.5296/jas.v9i1.18321

URL: https://doi.org/10.5296/jas.v9i1.18321

\begin{abstract}
The rhizosphere is the region that has direct influence from the roots. This is the place where most of the interactions between microorganisms and plants occur. Studies involving the ecology of microbial communities from the rhizosphere became more frequent after the first reports of biological interactions of microorganisms with plants that influence physically and chemically modify the soil surrounding. According to these hypotheses, the rhizosphere mycobiota provides the development of plants through various mechanisms, direct and indirect. Thus, the objective of this review was to explain the aspects that provide
\end{abstract}


characterizing these microorganisms as beneficial to plants in view of their applicability to agro-ecosystems. Therefore, it is stated that rhizospheric fungi have the solubilization of phosphorus (P), assimilating this nutrient for plants, promoting growth through the production or stimulation of the production of growth regulators such as 3-indole acetic acid, and control of phytopathogenic agents such as other filamentous fungi, and also phytonemamatodes. Therefore, it is possible to observe the importance of the constant observance of the action of these microorganisms in terms of their ecological role due to the agro-ecosystem.

Keywords: filamentous fungi, biological control, plant growth promoters, phosphorus solubilizing, phytohormones, ecological interactions

\section{Introduction}

The rhizosphere is the region of the soil that has direct influence from the roots due to its proximity to this plant organ. This is the place where most of the interactions between microorganisms and plants occur (Philippot et al., 2013), mutualistic or not. Thus, it is considered that this region is essential for the ecosystem due to the fact that there is a large flow of energy, having a strong impact on the functioning of the biosphere and other ecosystems (Berg et al., 2009).

Studies involving the ecology of microbial communities inhabiting the rhizosphere became more frequent after the first reports of biological interactions of microorganisms with plants (Kavamura \& Esposito, 2009). These physically and chemically modify the soil surrounding the roots through gas exchange, changes in the concentration of nutrients, production of secondary metabolites, changes in $\mathrm{pH}$, among other factors.

Given this importance, it is essential to understand the biological processes that occur in the rhizosphere, in view of the environmental impacts they cause, since the soil is understood as a living compartment and that houses an infinite number of organisms (Silva et al., 2019 ), which have desirable characteristics for application in agricultural management, especially with regard to the growth of plants, since the microorganisms that inhabit the soil and the rhizosphere have several features that provide plant growth, in addition to their close affinity with the plants.

Beneficial microorganisms such as actinomycetes, common bacteria and filamentous fungi have been studied for agricultural development, making it possible to use their functions to develop processes. The action of the soil microbiota provides benefits such as biological $\mathrm{N}$ fixation, phosphate solubilization and biological control of phytopathogens and agricultural pests, which has already been demonstrated in previous studies (Yuan et al., 2010; Silva et al., 2017; Vivas et al., 2018). In this sense, this systematic review sought to address the main mechanisms for promoting plant growth through the action of soil and/or rhizospheric fungi.

Thus, the objective of this systematic review is to approach the mechanisms of growth promotion in plants grown by means of rhizospheric fungi, making a connection between the mechanisms, how they occur and how they are interconnected in the synbiotic processes of growth promotion in plants, especially with regard to plant health. 


\section{Rhizospheric Fungi and Functionalities to Plant Growth Promotion}

Soil microorganisms are responsible for the degradation of different elements of soil organic matter, transformed into a variety of biomolecules and secondary metabolites, released via the action of various enzymes (Tortella et al., 2008). These compounds and biomolecules are appreciated in terms of assimilation by plants, which, when going through the cycling process, act as biofertilizers or can indirectly contribute to the performance of biota stability, metabolism, health and soil diversity.

Naturally, plants are colonized by numerous microorganisms, establishing various forms of symbiotic associations. These associations comprise the various mechanisms that make it possible to name these microorganisms as Plant Growth Promoters. Thus, among the most commonly known characteristics in agriculture we can mention the phosphate solubilization (Silva et al., 2015; Silva et al, 2019), production of hormones or plant growth regulators (Oliveira et al., 2018) and control of phytopathogens (Silva et al., 2017), which can act through various mechanisms (direct and indirect).

Recently, the association between wild rice species with diazotrophic bacteria (Zhang et al., 2008) and endophytic fungi "dark septate" (DSEF) (Yuan et al., 2010) has been reported. Some authors have suggested that DSEF have the ability to establish mutual associations with host plants, as they act as promoters of plant growth and, mainly, facilitate the absorption of phosphorus and nitrogen (Chen et al., 2010).

It has also been observed that these fungi can coexist with mycorrhizal fungi and produce metabolites capable of increasing the germination, growth and branching of hyphae of these fungi, benefiting the host plant indirectly (Scervino et al., 2009). This coexistence is an important factor, since, in the absence of competition between beneficial microorganisms in the soil, the greater the chances of promoting a better balance in the soil microbiota, favoring plant development. Unlike arbuscular mycorrhizal fungi, DSEF are not mandatory biotrophic fungi, which facilitates their cultivation in culture medium and the development of inoculants aimed at promoting plant growth, which is a favorable characteristic for a plant growth-promoting fungus.

Some strains of Trichoderma sp. (Silva et al., 2017) they have been widely studied because they increase the total surface of the root system, allowing a greater access to the mineral elements present in it. Others are capable of solubilizing and making available to the plant rock phosphate, iron, copper, manganese and zinc (Oliveira et al., 2012). They can also improve the active mechanisms of absorption of copper, phosphorus, iron, manganese, sodium, cobalt, cadmium, chromium, nickel, lead, vanadium, magnesium, boron, zinc and aluminum; as well as increasing the efficiency of the plant to use some important nutrients, such as nitrogen.

The inoculation of microorganisms, combined or not with other beneficial soil microorganisms, can increase plant development (Silva Filho \& Vidor, 2000; Narloch et al., 2002), which can be induced directly, by the production of growth hormones, or indirectly, by the modification of the rhizosphere microbiota. The latter is considered one of the main 
mechanisms of action, due to the suppression of harmful microorganisms (Melo \& Azevedo, 1998).

\subsection{Phosphate Solubilization}

Despite being abundant in soils, both in organic and inorganic form, phosphorus $(\mathrm{P})$ is the second nutrient limiting plant growth, after Nitrogen $(\mathrm{N})$. The low availability of this nutrient, especially in acidic soil conditions in tropical and subtropical regions, is considered one of the limiting factors for agricultural production. These characteristic stimulate the high applications of phosphate fertilizers, however the plants do not have the capacity to assimilate these applied concentrations, being a large part of this $\mathrm{P}$ lost by leaching.

This element is one of the main macronutrients essential for plant growth and development due to its performance in metabolic processes (Rocha et al., 2007). In general, Brazilian soils naturally have a low total phosphorus content and very low phosphorus content available to plants. Of the phosphorus added to the soil through chemical fertilizers, up to $25 \%$ is used by the plants. These fertilizations are carried out mainly with water-soluble phosphates, reaching phosphorus dosages much higher than the needs of the crops, since most of the added becomes unavailable to plants (Braga, 2006). This unavailability due to losses characterizes a financial loss for producers, as well as a risk of contamination of groundwater, thus making it necessary to use strategies that can mitigate this scenario.

Phosphate solubilizing microorganisms are those that have the ability to secrete organic acids, and/or phosphatases that facilitate the conversion of insoluble forms of phosphorus (P) (Figure 1) to forms available to plants (Moreira \& Araújo, 2013). In the soil P cycle, microorganisms are important factors, where organic $\mathrm{P}$ can be released through mineralization and inorganic $\mathrm{P}$ through hydrolysis of monoesters by alkaline and acid phosphomonoesterase. Plants release only acid phosphomonoesterase, while microorganisms can produce acid and alkaline. As a result, microorganisms demonstrate greater involvement in the P cycle, contributing to greater plant nutrition (Cui et al., 2015).

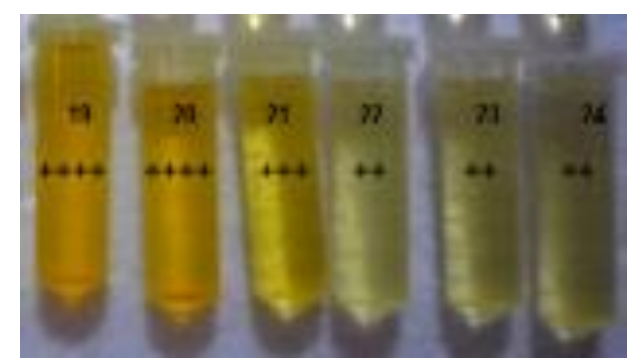

Figure 1. P solubilization. Higher yellow color indicates higher solubilization index by the microorganism. Adapted from Montaldo (2016)

These microorganisms play an important role in the supply of $\mathrm{P}$ to plants and their solubilizing action has been associated mainly with the production of organic acids (Barroso \& Nahas, 2008; Alves \& Silva Filho, 2009). In the soil, the P-solubilizing microorganisms contribute to increase the concentration of this element in the soil solution, making it able to be absorbed directly by the roots or by the fungi hyphae in symbiosis (Moreira \& Siqueira, 2006). 
Phosphorus is adsorbed to soil colloids or transformed into poorly soluble iron and aluminum compounds for plants. That is why fertilizer formulations are represented by high levels of $\mathrm{P}$. With this, greater amounts of $\mathrm{P}$ are added to the soil so that the plant can use $25 \%$, which translates into a low efficiency of phosphate fertilizers. In this sense, soil microorganisms have a transcendent role in phosphorus mineralization and solubilization. The organic forms of $\mathrm{P}$ are mineralized by the microorganisms producing phosphatase enzymes (Braga, 2006).

Organic $\mathrm{P}$ is transformed into soluble $\mathrm{P}$ by the action of phosphatases, enzymes that catalyze the hydrolysis of phosphate esters, releasing soluble phosphate. Phosphatases are secreted by plant roots and soil microorganisms (Nahas et al., 1994). This enzyme, when in the plant environment, can be constitutive or induced by external factors such as deficiency of inorganic phosphorus or difficulty in absorbing phosphorus in conditions of lack of water.

The activity of acid phosphatase has a significant correlation with inorganic phosphorus. The concentration of inorganic phosphorus in the plant tissue is a parameter of efficiency in the use of phosphorus. The lower the content of inorganic phosphorus in the tissue, the greater the activity of acid phosphatase in the mechanism of phosphorus use by plants.

The inoculation of phosphate solubilizing microorganisms in the soil has been suggested as an alternative to replace or decrease the use of soluble phosphate fertilizers, by making better use of the natural phosphates (Vessey, 2003) existing or added to the soil and those formed by the application of sources soluble, to increase the concentration of soluble phosphorus in the rhizosphere and to promote plant nutrition with phosphorus (Peix et al., 2001; Gyaneshwar et al., 2002). Thus, it can be understood that this is one of the alternatives for sustainable management of agro-ecosystems.

\subsection{Plant Growth Regulators Production}

Plant growth-promoting fungi benefit plants through direct mechanisms (phytohormone production, reduction of ethylene levels in the soil, phosphate solubilization) and indirect mechanisms, which include biocontrol mechanisms, production of antibiotics, induction of systemic resistance, among others, showing, diversified mechanisms which can be applied in agriculture (Oliveira et al., 2012; Aguado-Santacruz et al., 2012; Moreira \& Araújo, 2013).

Phytohormones or plant hormones are understood as chemical substances that in low concentrations promote the growth of plants, influencing their growth, development and cellular differentiation of tissues (Spaepen et al., 2009). They are signaling molecules that regulate many plant development processes (Fitze et al., 2005) are organic compounds, which are naturally produced in some part of the plant and at some point in its phenology, transported to another, which ends in physiological responses specific ones, and there are also those who act in the very place where they are produced.

Due to the ability to stimulate or inhibit the growth of plants, they are also called plant growth regulators. Five main groups of phytohormones are recognized: auxins, gibberellins, ethylene, cytokinins and abscisic acid (Egamberdieva et al., 2017). These phytohormones or phytoregulators are also fundamental in the processes of colonization of the root system towards symbiotic processes. 
Auxins are compounds that stimulate growth, with 3-indolacetic acid (IAA) being the main auxin found in plants, which is produced in the apical meristem of the stem, young leaves, flowers, developing fruits and seeds, being also found in roots. Its transport occurs unidirectionally, through phloem and parenchymal cells that circulate vascular tissues (Raven et al., 2005). These phytohormones are responsible for plant elongation and cell differentiation, being the most prospected due to the microorganisms that promote plant growth. Some of these microorganisms are able to stimulate the growth of plants by reducing the levels of ethylene in them, through the action of the enzyme 1-aminocyclopropane-1-carboxylate (ACC) deaminase, decreasing the production of ethylene in the roots of host plants, which results in the elongation of this plant organ (Figure 2).

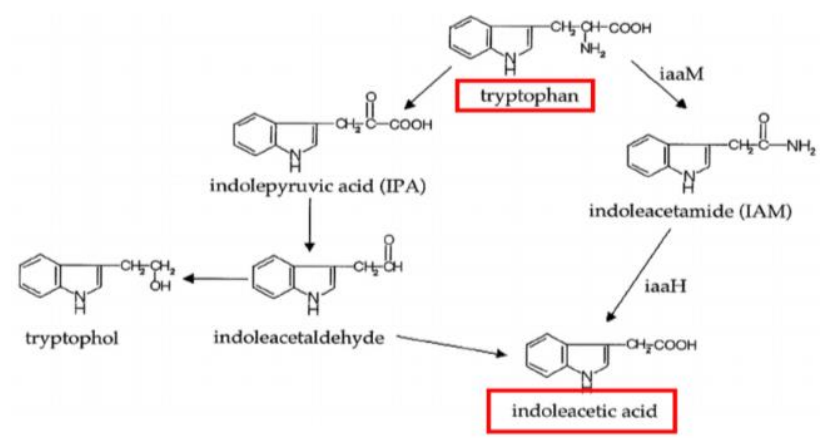

Figure 2. Biosynthesis of 3-indole-acetic acid using the precursor $L$-tryptophan

The promotion of root growth is one of the beneficial effects of microorganisms that promote plant growth, as the rapid establishment of lateral and adventitious roots is an advantageous feature for plants, increasing the ability to attach to the soil and obtain water and nutrients from the plant. environment (Moreira \& Araújo, 2013; Silva et al., 2015). In addition, fungi have the ability to act as "extensions" of plant roots, which fosters the skills previously mentioned.

Kaldorf and Ludwig-Müller (2000) observed that plants colonized by Arbuscular Mycorrhizal Fungi (AMFs) showed an increase in the biosynthesis and in the concentration of free idol-3-butyric acid (IBA) in their roots, at the same time that they present a significant increase on its side branch. According to the same authors, the increase in IBA percentages is related to the increase in plant-AMF interaction. According to Ludwig-Müller (2000), although the synthesis of phytohormones in plants colonized by AMFs is still poorly studied, there is evidence that the hormonal exchange between AMFs and host plants exists.

The amino acid $L$-tryptophan, functions as a physiological precursor in the biosynthesis of auxins in plants and microorganisms (Khalid et al., 2004). In the biosynthesis of Trp-independent AIA, glycerol-3-indole phosphate or indole is probably the precursor, however little is known about the biochemical pathway for IAA (Zhang et al., 2008). In the biosynthesis of Trp-dependent IAA, several pathways have been proposed: (i) Indol-3-Acetamide (IAM) pathway; (ii) Indole-3-30-Pyruvic Acid (IPA) route; (iii) tryptamine route (TAM) and (iv) indole route 3-Acetaldoxima (IAOX) (Normanly, 2010; Zhao, 2010). 


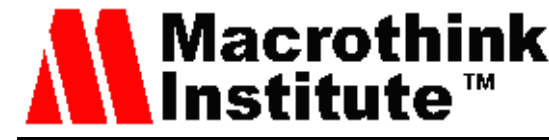

\subsection{Biological Mechanisms Against Phytopathogenic Agents}

The suppression of diseases by beneficial microorganisms in the rhizosphere can occur through several mechanisms of action, such as: antagonism related to the production of antibiotics, antifungals, competition for space and nutrients with phytopathogens and other microorganisms harmful to the rhizosphere and resistance induction in plants (Moreira \& Araújo, 2013) (Figure 3).

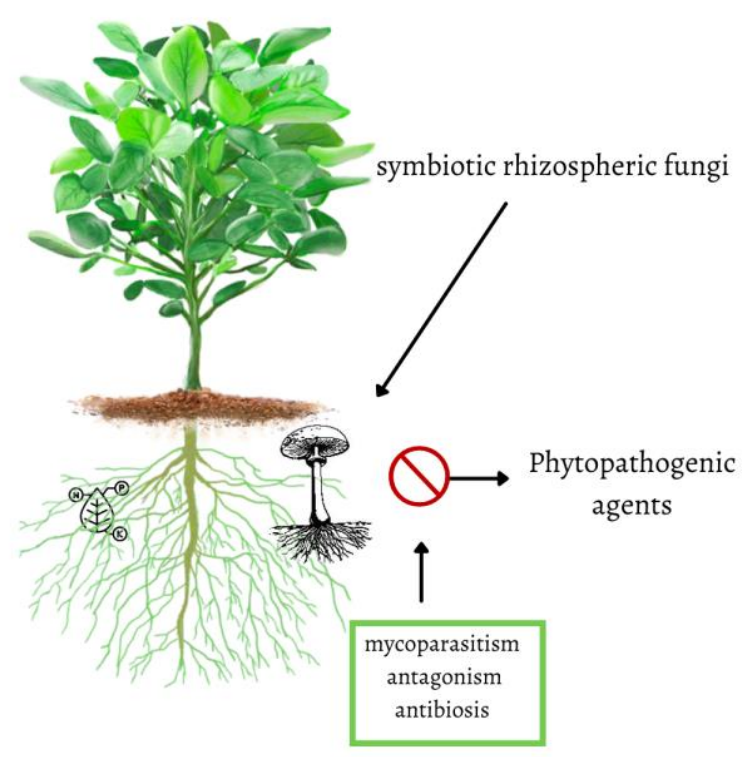

Figure 3. Graphical representation of the symbiotic relationship between fungi and plants against phytopathogenic agents

Considering biocontrol, there are several mechanisms of action used by these fungi, among which are the production of metabolites and enzymes with antifungal properties, hyperparasitism and competition for nutrients (Verma et al. 2007). These characters give these organisms a prominent place in research related to the biocontrol of plant diseases caused by fungi.

Biological control is characterized as a way of using microorganisms in order to limit the action of pathogens in the environment and/or increase the host's resistance to attack by these harmful agents (Morandi \& Bettiol, 2009). Thus, it is imperative to affirm the need for prospecting microorganisms not only based on their biological functions, but also to observe the relationships with the host and the environment.

Biological disease control is defined by the interaction between host, pathogen and some non-pathogens inhabiting the infection site. It can still be defined by the suppression of populations of plant pathogens by living organisms (Heimpel \& Mills, 2017), which play an important ecological role in the agricultural environment.

In this perspective of a model of extensive agriculture worldwide disseminated and seeking to meet the need for the production of commodities and food for the population, biological 
control turned out to be an area of studies involving different areas such as ecology, biosystematics, behavior, physiology and genetics, with the objective of subsidizing knowledge and acting not only in the microclimate in which the population is inserted, but also in the balance of the entire biological community of the soil (Cook \& Baker, 1983).

In order to apply biocontrol or biological control in plant diseases, we look for free-living microorganisms, or colonizers of plant surfaces and hyperparasites, fungi that parasitize other fungi (Silva et al., 2017) or, still, colonizers of internal plant tissues, which are called endophytes or edophytes.

Such biocontrol agents can act by several direct mechanisms of action such as competition, parasitism and direct antibiosis, or indirect mechanisms such as promoting plant growth and inducing resistance, being mechanisms that always act in parallel. There are reports in the specialized literature of a diversity of microorganisms, mainly fungi and bacteria, used to control phytopathogenic fungi (Pal \& Gardener, 2006; Morandi \& Bettiol, 2009; Silva et al., 2019).

The introduction of the biological control technique in the management of diseases in cultivated plants has been studied and applied for years, in order to reduce the uncontrolled use of chemical products, reducing their harmful and harmful effects on the environment, man and animals, as well as the cost reduction in the production of the crops of interest and benefiting the health of man and animals (Grigoleti Júnior et al., 2000). Thus, it is possible to affirm that the application of biological control techniques, especially with integrated pest management (IPM) is an alternative as a clean technology for agricultural production and food production.

The success in the use of antagonistic organisms in the control of plant diseases is related to the knowledge of the ecology and physiology of pathogen and antagonist. Therefore, it is necessary to know what is the resistance level supported by the antagonist, how is its behavior and growth in different substrates, what is its resistance to chemical products and how is the relationship between pathogen, host and the environment in which they are inserted (soil, plant, atmosphere, among others).

However, most of the studies carried out on the application of fungi in the biological control of plant diseases caused by fungi have been directed to the genus Trichoderma, due to the fact that it has notoriety for decades about its skills as a biocontroller as well as the greater ease of use. registration of products obtained through their lineages. However, it is necessary to study other species with potential antagonists against phytopathogens. In this sense, Vivas et al. (2018) demonstrates in his study the potential application of other species of filamentous fungi in the control of phytopathogenic fungi, highlighting the genera Acremonium and Sarocladium. As Köhl et al. (2019) that studying antagonistic candidates talk about the genera Aspergillus and Cladosporium, which demonstrates that the species should be studied further, especially when it comes to the production of potentially inhibitory metabolites to phytopathogenic fungi. It is also worth noting that rhizospheric fungi have action against other organisms harmful to plants such as nematodes and bacteria. 
In addition, it is important to highlight the role of these microorganisms in the control of phytopathogenic nematodes, as shown by Barbosa et al. (2019) that the fungus Pochonia chlamydopsporia can be used in the culture of bananas in the control of the gall nematode as well as improving the development of the plants, since this fungus has affinity with the root system.

In addition to promoting efficient control of nematodes, when in their absence, $P$. chlamydosporia is able to survive in the rhizosphere of many plants and to use organic matter as an additional source of nutrients (Coutinho et al., 2009), which means that is a desirable feature for field application. Furthermore, it is an optional parasite of eggs of gall and cyst nematodes and its infectious process involves the production of enzymes that remove the protein membrane from the egg, exposing the underlying chitin layer (Morton et al., 2003).

The species Arthrobotrys oligospora Fresen forms a typical network of adhesive traps, formed by an agglomeration of innumerable rings with three cells (Nordbring-Hertz, 2004), which provides for the nematodes imprisonment preventing their mobility, consequently affecting their development. These traps can be formed immediately after the germination of Arthrobotrys spp. conidia (Hahn et al., 2018).

Beauveria bassiana (Bals. Criv., 1836) Vuill. it is known to be used in the biological control of insects, as it is an entomophagous fungus that inhabits the soil and is commonly associated with entomophagy in coleopterans of agricultural interest, such as Rhynchophorus palmarum (Lima et al., 2020). However, the effect of this fungus on nematodes is due to the synthesis of numerous toxins (Liu et al., 2008), which are secondary metabolites produced by these fungi and which act on the insect's olfactory system.

Even when it comes to entomopathogenic species inhabiting the soil and rhizosphere, fungi of the genus Metarhizium are generally used to control insect pests, however, isolates of Metarhizium have the potential to control gall nematodes (Sun et al., 2006). Thus, this information shows the importance of using biocontrollers in the IPM due to its breadth of action for the benefit of plant health.

From this perspective and with the hypotheses raised through the scientific evidence explained here, it is possible to infer the importance of studies related to rhizospheric fungi as to their importance in agricultural management, especially due to the ecological relationships existing between these microorganisms and the plants cultivated through their mechanisms of action such as plant growth promoters and resistance inducers in plants.

\section{Final Considerations}

The theories and discussions outlined here as a systematic review are a contribution to understanding the ways in which fungi are an extremely important group of organisms for the development of agroecosystems and ecological balance for plant populations, especially those found in environments considered extreme or that have undergone natural or anthropogenic degradation processes.

This approach becomes important because the majority of the review works are directed to 
only one of the study areas of growth-promoting fungi, and it is not presented in a joint and complementary way, as most of the research is focused on bacteria, rhizobacteria. or endophytic fungi.

\section{References}

Aguado-Santacruz, G. A., Moreno-Gómez, B., Jiménez-Francisco, B., García-Moya, E., \& Preciando-Ortiz, R. E. (2012). Impacto de lós sideróforos microbianos y fitosideróforos en la asimilácion de hierro por las plantas: uma síntesis. Revista Fitotecnia Mexicana, 35(1), 9-21. https://doi.org/10.35196/rfm.2012.1.9

Alves, L., \& Silva Filho, G. N. (2009). Produção de mudas de alface (Lactuca sativa L.) em presença de diferentes fontes fosfatadas e microorganismos solubilizadores de fosfatos. Semina: Ciências Agrárias, 30(3), 557-562.

https://doi.org/10.5433/1679-0359.2009v30n3p557

Barbosa, R. T., Monteiro, T. S. A., Coutinho, R. R., Silva, J. G., \& Freitas, L. G. (2019). Pochonia chlamydosporia for controlling root-knot nematode in banana. Nematropica, 49, 99-106.

Barroso, C. B., \& Nahas, E. (2008). Solubilização do fosfato de ferro em meio de cultura. Pesquisa Agropecuária Brasileira, 43(4), 529-535.

https://doi.org/10.1590/S0100-204X2008000400012

Berg, G. (2009). Plant-microbe interactions promoting plant growth and health: perspectives for controlled use of microorganisms in agriculture. Applied Microbiolology and Biotechnology, 84(1), 11-18. https://doi.org/10.1007/s00253-009-2092-7

Braga, G. (2006). Eficiência de fosfatos com solubilidade variável em água em solos com capacidade de fixação de fósforo induzida. (Doctoral Theis). Escola Superior de Agricultura Luiz de Queiroz, São Paulo.

Chen, X. M., Dong, H. L., Hu, K. X., Sun, Z. R., Chen, J. A., Guo, S. X. (2010). Diversity and antimicrobial and plant-growth-promoting activities of endophytic fungi in Dendrobium loddigesii Rolfe. Journal of Plant Growth Regulation, 29, 328-337.

https://doi.org/10.1007/s00344-010-9139-y

Cook, R. J., \& Baker, K. F. (1983). The nature and practice of biological control of plant pathogens. St. Paul: American Phytopathological Society, 539p.

Coutinho, M. M., Freitas, L. G., Dallemole-Giaretta, R., Neves, W. S., Lopes, E. A., \& Ferraz, S. (2009). Controle de Meloidogyne javanica com Pochonia chlamydosporia e farinha de sementes de mamão. Nematologia Brasileira, 33(2), 169-175.

Cui, H., Zhou, Y., Gu, Z., Zhu, H., Fu, S., \& Yao, Q. (2015). The combined effects of cover crops and symbiotic microbes on phosphatase gene and organic phosphorus hydrolysis in subtropical orchard soils. Soil Biology and Biochemistry, 82, 119-126.

https://doi.org/10.1016/j.soilbio.2015.01.003 
Egamberdieva, D., Wirth, S. J., Alqarawi, A. A., Abd Allah, E. F., \& Hashem, A. (2017). Phytohormones and Beneficial Microbes: Essential Components for Plants to Balance Stress and Fitness. Frontiers in microbiology, 8, 2104. https://doi.org/10.3389/fmicb.2017.02104

Fitze, D., Wiepning, A., Kaldorf, M., \& Ludwig-Müller, J. (2005). Auxins in the development of an arbuscular mycorrhizal symbiosis in mayze. Journal of Plant Physiology, 162(11), 1210-1219. https://doi.org/10.1016/j.jplph.2005.01.014

Grigoletti Júnior, A., Dos Santos, A. F., \& Auer, C. G. (2000). Perspectivas do uso do controle biológico contra doenças florestais. Floresta, 30(1/2), 155-165. https://doi.org/10.5380/rf.v30i12.2362

Gyaneshwar, P., Naresh Kumar, G., Parekh, L. J., \& Poole, P. S. (2002). Role of soil microorganisms in improving $\mathrm{P}$ nutrition of plants. Plant and Soil, 245(1), 83-93. https://doi.org/10.1023/A:1020663916259

Hahn, M. H., Duarte, H. S. S., Mio, L. L. M., \& Kuhn, O. J. (2018). Levantamento Bibliométrico De Fungos Nematófagos No Controle Dos Nematoides Das Galhas. Scientia Agraria Paranaensis, 17(4), 389-397.

Heimpel, G. E., \& Mills, N. J. (2017). Biological control: ecology and applications. 2017. https://doi.org/10.1017/9781139029117

Kaldorf, M., \& Ludwig-Müller, J. (2000). AM fungi might affect the root morphology of maize by increasing indole-3-butyric acid biosynthesis. Plant Physiology, 109(1), 58-67, 2000. https://doi.org/10.1034/j.1399-3054.2000.100109.x

Kavamura, N. V., \& Esposito, E. (2009). Biotechnological Strategies Applied to the Decontamination of Soils Polluted with Heavy Metals. Biotechnology advances, 28, 61-9. https://doi.org/10.1016/j.biotechadv.2009.09.002

Khalid, A., Arshad, M., \& Zahir, Z. (2004). Screening plant growth-promoting rhizobacteria for improving growth and yield of wheat. Journal of Applied Microbiology, 96(3), 473-480. https://doi.org/10.1046/j.1365-2672.2003.02161.x

Köhl, J., de Geijn, H.-V., Haas, L.-d., Henken, B., Hauschild, R., Hilscher, U., der Plas, C. V., vanden Bosch, T., \& Wikström, M. (2019). Stepwise screening of candidate antagonists for biological control of Blumeria graminisf. sp. Tritici. Biological Control, 136, 104-108. https://doi.org/10.1016/j.biocontrol.2019.104008

Lima, H. M. A., de Melo Rodrigues, V., Rodrigues Sabino, A., Cardoso dos Santos, M. Q., Soares de Lima, I., Guimarães Duarte, A., Negrisoli Junior, A. S., \& Silva, J. M. (2020). Effect of isolates of entomopathogenic fungi in the coconut eye borer. Comunicata Scientiae, 11, e3300. https://doi.org/10.14295/cs.v11i0.3300

Liu, T., Wang, L., Duan, Y. X., \& Wang, X. (2008). Nematicidal activity of culture filtrate of Beauveria bassiana against Meloidogyne hapla. World Journal of Microbiology and Biotechnology, 24(1), 113-118. https://doi.org/10.1007/s11274-007-9446-z 
Ludwig-Müller, J. (2000). Hormonal balance in plants during colonization bymycorrhizal fungi," In: Arbuscular Mycorrhizas: Physiology and Function, eds Y.Kapulnik and D. D. Douds (Dordrecht: Springer). https://doi.org/10.1007/978-94-017-0776-3_12

Medrado, P. H. S. (2019). Fungos de solo no controle biológico de Fitopatógenos. (Master Deegree Dissertation). Universidade Federal de Santa Catarina, Santa Catarina.

Melo, I. S., \& Azevedo, J. L. (1998). Ecologia microbiana. Jaguariúna: Embrapa-CNPMA, 488p.

Montaldo, Y. C. Bioprespecção e isolamento bacterias associadas à cana-de-açúcar (Saccharum officinarum L.) com características para a promoção de crescimento vegetal. (Doctoral Thesis), Rede Nordeste de Biotecnologia, Alagoas, Brazil.

Morandi, M. A. B., \& Bettiol, W. (2009). Controle biológico de doenças de plantas no Brasil: marcos históricos do controle biológico de doenças de plantas no Brasil. In: Biocontrole de doenças de plantas: uso e perspectivas. Ed(s). Embrapa Meio Ambiente, Jaguariúna, São Paulo, pp. 08-14.

Morandi, M. A. B., \& Bettiol, W. (2009). Controle biológico de doenças de plantas no Brasil: marcos históricos do controle biológico de doenças de plantas no Brasil. In: Morandi, M. A. B., \& Bettiol, W. Biocontrole de doenças de plantas: uso e perspectivas. Embrapa Meio Ambiente, Jaguariúna, São Paulo, p. 08-14.

Morandi, M. A. B., Paula Júnior, T. J., Bettiol, W., \& Teixeira, H. (2009). Controle biológico de fungos fitopatogênicos. Informe Agropecuário, 30(251), 73-82.

Moreira, A. L. L., \& Araújo, F. F. (2013). Bioprospecção de isolados de Bacillus spp. Como potenciais promotores de crescimento de Eucalyptus urograndis. Revista Árvore, 37(5), 933-943. https://doi.org/10.1590/S0100-67622013000500016

Moreira, F. M. S., \& Siqueira, J. O. (2006). Microbiologia e bioquímica do solo. 2 ed. Lavras: Editora UFLA, 729p.

Morton, C. O., Hirsch, P. R., Peberdy, J. P., \& Kerry, B. R. (2003). Cloning of and genetic variation in protease VCP1 from the nematophagous fungus Pochonia chlamydosporia. Mycological Research, 107, 1, 38-46. https://doi.org/10.1017/S0953756202007050

Nahas, E., Centurion, J., \& Assis, L. (1994). Efeito das características químicas dos solos sobre os microrganismos solubilizadores de fosfato e produtores de fosfatases. Revista Brasileira de Ciencia do Solo, 18(1), 49-53.

https://doi.org/10.1590/S0006-87052002000300008

Narloch, C., Oliveira, V. L., Anjos, J. T., \& Silva Filho, G. (2002). Respostas da cultura do rabanete à inoculação de fungos solubilizadores de fosfatos. Pesquisa Agropecuária Brasileira, 37(6), 841-845. https://doi.org/10.1590/S0100-204X2002000600013

Nordbring-Hertz, B. (2004). Morphogenesis in the nematode-trapping fungus Arthrobotrys oligospora - an extensive plasticity of infection structures. Mycologist, 18(3), 125-133. 
https://doi.org/10.1017/S0269915X04003052

Normanly, J. (2010). Approaching cellular and molecular resolution of auxin biosynthesis and metabolism. Cold Spring Harbor Perspectives in Biology, 2(1).

https://doi.org/10.1101/cshperspect.a001594

Oliveira, A. G., Chagas Junior, A. F., Santos, G. R., Miller, L. O., \& Chagas, L. F. B. (2012). Potencial de solubilização de fosfato e produção de AIA por Trichoderma spp. Revista Verde de Agroecologia e Desenvolvimento Sustentável, 7(3), 149-155. https://doi.org/10.18378/rvads.v7i3.1338

Pal, K. K., \& Gardener, B. M. Biological control of plant pathogens. The plant health Instructor. Available on:

<https://pdfs.semanticscholar.org/57c8/b8182119510f548c56be5f0496ac1924c484.pdf>

Accessed on: september 2020.

Peix, A., Rivas-Boyero, A. A., Rodriguez-Barrueco, C., Martínez-Molina, E., \& Velasquez, E. (2001). Growth promotion of chickpea and barley by a phosphate solubilizing strain of Mesorhizobium mediterraneum under growth chamber conditions. Soil Biology and Biochemistry, 33(1), 103-110. https://doi.org/10.1016/S0038-0717(00)00120-6

Philippot, L., Raaijmakers, J. M., Lemanceau, P., \& Der Putten, W. H. V. (2013). Going back to the roots: the microbial ecology of the rhizosphere. Nature Reviews Microbiology, 11, 789-799. https://doi.org/10.1038/nrmicro3109

Raven, P. H., Evert, R. F., \& Eichhorn, S. E. (2005). Biology of plants. [S.1.]: Macmillan.

Rocha, F. R., Papini-Terzi, F. S., Nishiyama Junior, M. Y., Vêncio, R. Z. N., Vicentini, R., Duarte, R. D. C., Rosa Junior, V. E., Vinagre, F., Barsalobres, C., Medeiros, A. H., Rodrigues, F. A., Ulian, E. C., Zingaretti, S. M., Galbiatti, J. A., Almeida, R. S., Figueira, A V. O., Hemerly, A. S., Silva Filho, M. C., Menossi, M., \& Souza, G. M. (2007). Signal transduction related responses to phytohormones and environmental challenges in sugarcane. $B M C$ Genomics, 8(1). https://doi.org/10.1186/1471-2164-8-71

Saharan, B., \& Nehra, V. (2011). Plant growth promoting rhizobacteria: a critical review. Life Sciences and Medical Research, 21, 1-30.

Scervino, J. M., Gottlieb, A., Silvani, V. A., Pergola, M., Fernandez, L., \& Godeas, A. M. (2009). Exudates of dark septate endophyte (DSE) modulate the development of the arbuscular mycorrhizal fungus (AMF) Gigaspora rosea. Soil Biology and Biochemistry, 41, 1753-1756. https://doi.org/10.1016/j.soilbio.2009.04.021

Silva Filho, G. N., \& Vidor, C. (2000). Solubilização de Fosfato por Microrganismos na presença de fontes de carbono. Revista Brasileira de Ciência do Solo. 24, 311-319. https://doi.org/10.1590/S0100-06832000000200008

Silva, J. M., Cristo, C. C. N., Montalto, Y. C., Silva, C. S., Sena, E. O. A., Vigoderis, R. B., ... Santos, T. M. C. (2019). Microbial activity and population of a red-yellow podzolic soil under organic and conventional cultivation systems of Citrus sinensis (L.) Osbeck. 
Revista de Ciências Agrárias, 42(2), 340-346. doi.org/10.19084/rca.17172

Silva, J. M., Nascimento, S. P. G., Massahud, R. T. R., Santos, T. M. C., \& Lima, G. S. A. (2019). Atributos químicos e biológicos do solo: Um estudo no Semiárido Alagoano. In: Gomes, I. A., Medeiros, M. B., Batista, M. C., Gonzaga, K. S., Felix, R. J. S., Silva Junior, J. M., \& Santos, J. P. O. Ensaios interdisciplinares em ciências agrárias no Nordeste do Brasil, Ananindeua: Itacaiúnas, pp. 42-80.

Silva, J. M., Santos, T. M. C., Albuquerque, L. S., Montaaldo, Y. C., Oliveira, J. U. L., Silva, S. G. M., ...Teixeira, R. R. O. (2015). Potential of the endophytic bacteria (Herbaspirillum spp. and Bacillus spp.) to promote sugarcane growth. Australian Journal of Crop Science, 9(8), 754-760.

Silva, J. M., Teixeira, R. R. O., Rocha, J. R., \& Santos, T. M. C. (2017). In vitro and in vivo antagonism of Screrotium rolfsii Sacc by strains of Trichoderma spp.. International Journal of Agriculture, Environment and Bioresearch, 2(1) 60-67.

Spaepen, S., Vanderleyden, J., \& Remans, R. (2007). Indole-3-acetic acid in microbial and microorganism-plant signaling. FEMS microbiology Reviews, 31(4), 425-448. https://doi.org/10.1111/j.1574-6976.2007.00072.x

Sun, M. H., Gao, L., Shi, Y. X., Li, B. J., \& Liu, X. Z. (2006). Fungi and actinomycetes associated with Meloidogyne spp. eggs and females in China and their biocontrol potential. Journal of Invertebrate Pathology, 93(1), 22-28. https://doi.org/10.1016/j.jip.2006.03.006

Tortella, G. R., Rubilar, O., Gianfreda, L., Valenzuela, E., \& Diez, M. C. (2008). Enzymatic characterization of Chilean native wood-rotting fungi for potential use in the bioremediation of polluted environments with chlorophenols. World Journal of Microbiology and Biotechnology, 24, 2805-2818. https://doi.org/10.1007/s11274-008-9810-7

Verma, M., Brar, S. K., Tyagi, R. D., Surampalli, R. Y., \& Valéro, J. R. (2007). Antagonistic fungi, Trichoderma spp.: Panoply of biological control. Biochemical Engineering Journal, 37(1), 1-20. https://doi.org/10.1016/j.bej.2007.05.012

Vessey, J. K. (2003). Plant growth promoting rhizobacteria as biofertilizers. Plant and Soil, 255(2), 571-586. https://doi.org/10.1023/A:1026037216893

Vivas, J. M. S., Silveira, S. F., Santos, P. H. D., Carvaho, B. M., Poltronieri, T. P. S., Jorge, T. S., ... Moraes, R. (2018). Antagonism of fungi with biocontrol potential of papaya black spot caused by Asperisporium caricae. Australian Journal of Crop Science, 12(05), 827-833. https://doi.org/10.21475/ajcs.18.12.05.PNE1073

Yuan, Z. L., Lin, F. C., Zhang, C. L., \& Kubicek, C. P. (2010). A new species of Harpophora (Magnaporthaceae) recovered from healthy wild rice (Oryza granulata) roots, representing a novel member of a beneficial dark septate endophyte. FEMS Microbiology Letters, 307, 94-101. https://doi.org/10.1111/j.1574-6968.2010.01963.x

Zhang, R., Wang, B., Ouyang, J., Li, J., \& Wang, Y. (2008). Arabidopsis Indole Synthase, a Homolog of Tryptophan Synthase Alpha, is an Enzyme Involved in the Trp-independent 


\section{Macrothink}

Journal of Agricultural Studies

ISSN 2166-0379 2021, Vol. 9, No. 1

Indole-containing Metabolite Biosynthesis. Journal of Integrative Plant Biology, 50(9), 1070-1077. https://doi.org/10.1111/j.1744-7909.2008.00729.x

Zhao, J. L., Zhou, L. G., \& Wu, J. Y. (2010). Promotion of Salvia miltiorrhiza hairy root growth and tanshinone production by polysaccharide-protein fractions of plant growth-promoting rhizobacterium Bacillus cereus. Process Biochemistry, 45(9), 1517-1522. https://doi.org/10.1016/j.procbio.2010.05.034

\section{Copyright Disclaimer}

Copyright for this article is retained by the author(s), with first publication rights granted to the journal.

This is an open-access article distributed under the terms and conditions of the Creative Commons Attribution license (http://creativecommons.org/licenses/by/4.0/). 